\title{
Effect of the Solvent Type on Phenolic and Flavonoid Substances and Antioxidant Properties of Leaves of 15 Medicinal Plants in Roodān Region of Southern Iran
}

\author{
Mojib Salehi Balashahri*1 $^{(1 D}$, Azar Davari², Bahman Fazeli Nasab ${ }^{3,4}$ (D) \\ ${ }^{1}$ Dept of Agriculture, Islamic Azad University, Roodān Branch, Roodān, Iran \\ ${ }^{2}$ Dept of Plant Production and Genetics, Faculty Of Agriculture, Vali-e-Asr University of Rafsanjan, Rafsanjan, Iran \\ ${ }^{3}$ Dept of Agronomy and Plant Breeding, Agricultural Research Institute, University of Zabol, Zabol, Iran \\ ${ }^{4}$ Dept of Plant Breeding and Biotechnology, Faculty of Agriculture, Ferdowsi University of Mashhad, Mashhad, Iran
}

Article Info A B S T R A C T

\section{Article type:}

Research article

\section{Article History:}

Received: 02 January 2021

Revised: 23 January 2021

Accepted: 23 June 2021

\section{* Correspondence to:}

Mojib Salehi Balashahri

Dept of Agriculture, Islamic Azad University, Roodān Branch, Roodān, Iran

Email: m.salehibalash@gmail.com
Introduction: Phenolic compounds and flavonoids have several biological properties, such as antioxidant properties, trapping free radicals, and anti-inflammatory properties. Different solvents have different capabilities in extracting phenolic materials and antioxidant properties. This study aimed to investigate and compare the different plants in the south of Iran regarding phenolic content and antioxidant properties; moreover, it was attempted to evaluate the effect of the solvent type on the mentioned issues. Material \& Methods: A total of 15 genotypes of medicinal plants (Ficus religiosa L, Terminalia catappa, Ficus carica, Cordia myxa, Black mulberry, Grewia asiatica, Psidium guajava, Mangifera 1, Mangifera 2, Eucalypteae, Syzygium cumini, Ziziphus 1, Citrullus colocynthis, Ziziphus 2, Punica granatum) were obtained from Roodān region (Hormozgan Province in Iran) and were also evaluated based on two types of methanolic and acetone extracts in terms of antioxidant properties, as well as phenolic and flavonoid substances in a factorial design in a completely randomized format with three replications. Data were analyzed using Statistic software (version 10), and the means were compared using the least significant difference at a $1 \%$ probability level. Findings: The results of the analysis of variance showed that the mutual effect of the plant and antioxidant properties (based on the DPPH) for acetone and methanolic extracts was significant at a $1 \%$ probability level. In the use of acetone solvent, the highest amount of phenol was in eucalyptus $(7.43 \mathrm{mg} / \mathrm{gFW})$, followed by Syzygium cumini (Java Plum) $(6.52 \mathrm{mg} / \mathrm{gFW})$. Furthermore, the highest amount of flavonoids was in mango $1(23.21 \mathrm{mg} / \mathrm{gFW})$, followed by Terminalia catappa (Indian-almond) $(18.75 \mathrm{mg} / \mathrm{gFW})$ and eucalyptus $(15.36 \mathrm{mg} / \mathrm{gFW})$. The most antioxidant properties were in Psidium guajava (Guava) (85.24\%), followed by Ziziphus mauritiana 1 (Jujube 1) $(82.68 \%)$ and Terminalia catappa (Indian-almond) $(82.31 \%)$. In the use of methanol solvent, the highest amount of phenol was in Syzygium cumini (Java Plum) (7.82 $\mathrm{mg} / \mathrm{gFW}$ ), followed by eucalyptus ( $7.34 \mathrm{mg} / \mathrm{gFW})$. In addition, the highest amount of flavonoids was in Terminalia catappa (Indian-almond) (mangroves) and mango 1 (24.46 mg/gFW and $25.06 \mathrm{mg} / \mathrm{gFW}$, respectively) and then Grewia asiatica (Phalsa) $(16.07 \mathrm{mg} / \mathrm{gFW})$ and Ziziphus mauritiana 1(Jujube 1) $(13.51 \mathrm{mg} / \mathrm{gFW})$. The highest antioxidant properties were obtained from Terminalia catappa (Indian-almond) $(82.07 \%)$, pomegranate $(78.97 \%)$, and Ziziphus mauritiana 1(Jujube 1) $(78.16 \%)$.

Discussion \& Conclusion: The most critical solvent for the extraction of phenol and Flavonoid substances with high oxidative properties is acetone. The most useful plants in terms of the presence of materials and antioxidant properties were Terminalia catappa (Indian-almond) and Ziziphus mauritiana (Jujube).

Keywords: DPPH, Psidium guajava, Syzygium cumini, Terminalia catappa, Ziziphus mauritiana

$>$ How to cite this paper

Salehibalashahri M, Davari A, Fazelinasab B. Effect of the Solvent Type on Phenolic and Flavonoid Substances and Antioxidant Properties of Leaves of 15 Medicinal Plants in Roodān Region of Southern Iran. Journal of Ilam University of Medical Sciences. 2022;29(5): 1-11. 


\title{
(1)
}

IDST-FVTA :P-ISSN

JIUMS

تأثير نوع حلال بر ميزان مواد فنلى، فلاونوئيدى و خواص آنتىاكسيدانى برك پانزده

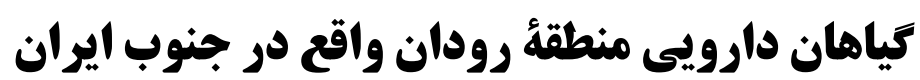

\author{
(iD) $r$

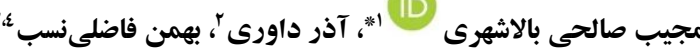

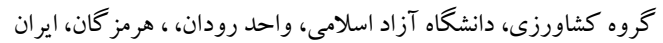

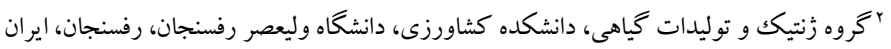

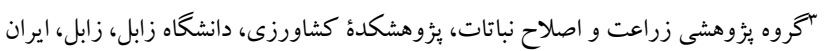

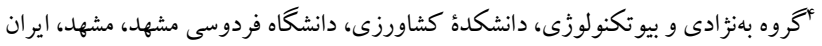

\begin{tabular}{ll}
\hline جهيده \\
\hline
\end{tabular}

مقدمه: تركيبات فنلى و فلاونوئيدها خواص بيولوزيكى متعددى مانند خاصيت آنتىاكسيدانى، به دام انداختن نوع مقاله: يُزوهشى

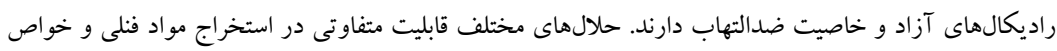

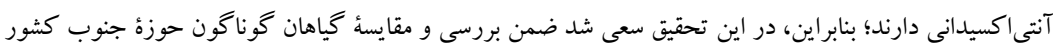

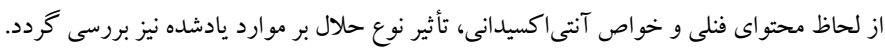

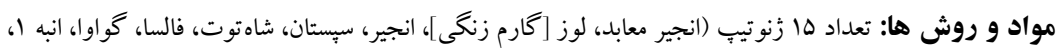

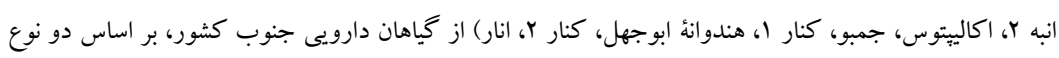

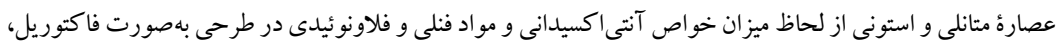

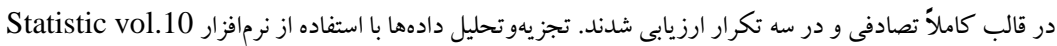

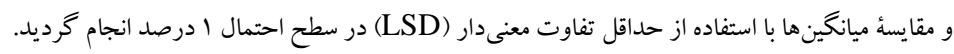

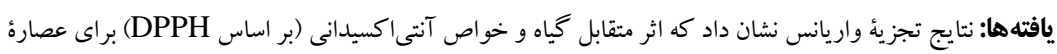

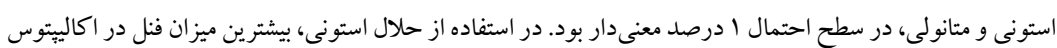

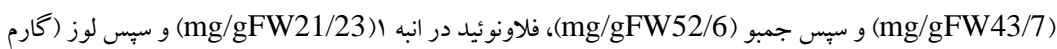

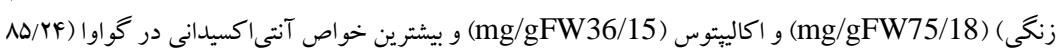

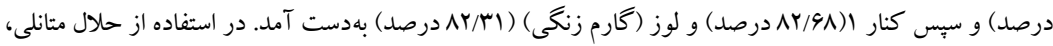

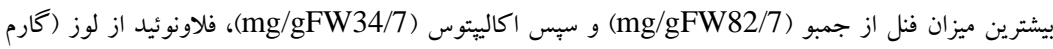

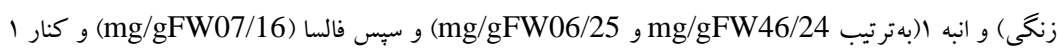
V و بيشترين خواص آنتىاكسيدانى از لوز (كارم زنخى) (mg/gFW51/13)

$$
\text { درصد) و كنار IVN/19 د دوصد) حاصل شد. }
$$

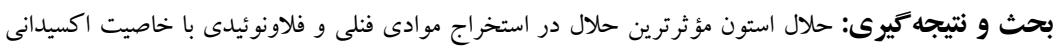

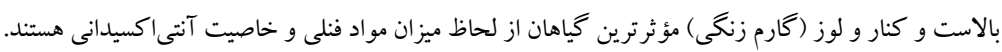

$$
\text { وازههاى كليدى: گَارم زنخى، جمبو، گواوا، كنار، DPPH }
$$

< استناد: صالحى بالاشهرى، مجيب؛ داورى، آذر؛ فاضلىنسب، بهمن. تأثير نوع حلال بر ميزان مواد فنلى، فلاونوئيدى و خواص آنتىاكسيدانى بركى پانزده

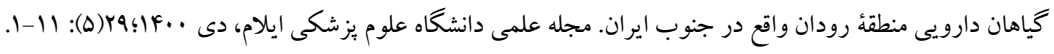


در نقاط مختلف جهان به نوع رزيم غذايى مردم منطقه وابسته است؛ براى مثال، در كشورهايى همجون زاين و جين، مصرف جاى سبز تأمين كنندهُ اين تركيبات موردنياز بدن است، درحالى كه اين مواد در كشورهاى غربى، با مصرف سيب و بياز و در كشورهاى شرقى، با مصرف سبزىهاو مواد غذايى تخميرى تأمين مىشوند (9). در كشور ايران، بهطور جامع نوع خاص استفاده از انواع مواد حاوى آنتىاكسيدان

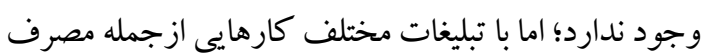
سبزىها بهصورت خام و ويخته، برگك گياهان و درختان مختلف (بهصورت دمنوش، عرقيات، عطرمايه، عصاره، مربا، شربت، ترشى، مواد شوينده ازجمله سدر و حتى مصرف بهصورت دلمه و غيره) صورت گرفته كه بيرو تحقيقات گوناگون، بايد از اندامهاى مختلف گياهان كه نوع ويثزاى از مواد آنتى اكسيدانى دارند، از آنها استفاده خاصى بشود. كزارششده است كه گياهان حاوى تركيبهاى فلاونوئيدى، فعاليت آنتى اكسيدانى بالايى از خود نشان

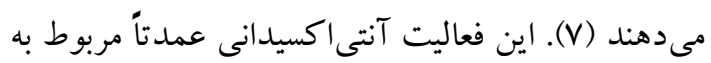
توانايى اين تركيبها به دادن الكترون يا اتمهاى هيدروزن است و به همين سبب، از نظر دارويى اهميت

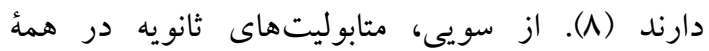
قسمت هاى مختلف گياهى مانند بركَ، ميوه، دانه، ريشه

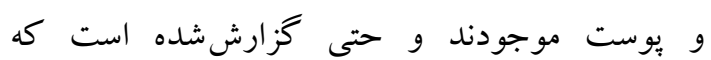
بخشهاى بذر و بوست برخى ميوهها از فعاليت آنتىاكسيدانى بيشترى حتى نسبت به به برخوردارند؛ بهعنوان نمونه، بذرهاى انكُور و يوست انار فعاليت آنتى اكسيدانى بيشترى نسبت به گوشت دارند و غنى از برو آنتوسيانيدين هستند كه مهار كننده نيرومند راديكالهاى فعال اكسيززن است (9)؛ بنابر اين، با توجه به شيوع بالاى بيمارى هاى مزمن و فرسايشى منطقى است كه براى تأمين آنتى اكسيدانهاى موردنياز بدن از گياهان استفاده شود و بهويزه گياهانى كه فنل و فلاونوئيد تام بالايى داشته باشند (11، ·(1)؛ درنتيجه، براى تأمين آنتى اكسيدانهاى طبيعى موردنياز بدن، مصرف گياهان با بـ

\section{مقدمه}

متابوليت هاى ثانويسهُ كياهـان دارويسى مانــــ اسانس (عطرمايه)ها و و عصارههاى گياهى از نظر آثار ضدميكروبى شان بررسسى شدهاند ( (1) و تخمين زدهشده است كه دست كم يككسوم همة فر آوردههاى دارويى منشأ كياهى دارند يا بس از استخراج از كياه تغيير شكل يافتهاند (Y)، بهطورى كه از ايسن مـواد عـلاوه بـر جلو گيرى از رشد باكترىها و كيككهاى آلوده كننده

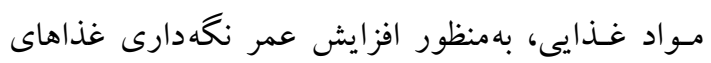
فرايندشده در سيستم غذايى و نيز افزايش عمر نكهدارى ميوهها و سبزىها استفاده گرديده است (ب). گزارشها بيانكر آن است كه بسيارى از عطرمايه هاى گياهى اثر بازدارند گیى جشمخيرى بر ميكروار گانيسمهاى بيمارىزا دارند و مشخص شده اسـت كه اغلـب عطرمايههاى گيـاهى استخراجشده از گياهان دارويى

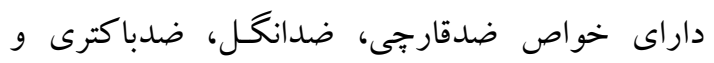
ضدويروس هستند؛ بنابراين، عطرمايههاى گياهى در

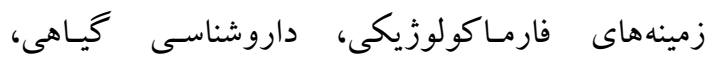
ميكروبيولـوزى ويزشكى و كلينيكى، فيتوياتولوزى و و نخه دارى مواد غذايى، ميوهها و سبزىها شديداً غربالخرى و استفاده شـدهاند. داروهاى گياهى نزد مردم مقبوليت بيشترى در مصرف دارند. اين دلايل علت افزايش موج جديد مطالعات كسترده جهانى و معرفى آثار ضدباكترى كياهان مختلف در سالهاى اخير بوده است. از سويى، مصرف مدام و بـىروية تر كيبات دارويى شـيميايى باعثث ايجاد يديدهُ مهم مقاومت نسبت به ميكروار گانيسمها مى شود و بـا ايجـاد اين يديده، اثر داروهـا ضـعيف و يـا

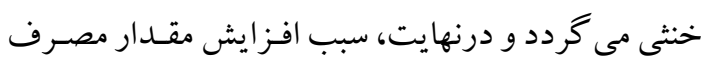
دارو و تمايسل بـه اسـتفاده از تركيبـات با فرمولاسيون جديدتر و قوىتر مىشود؛ همجنين ايراد ديخـر استفاده از ايسن داروها افزايش آثار جانبى آنهاست كه به ايجاد بيمارىهايى منجر مى مردد كه از بيمارى اوليه خطرناكك تر است (ه، F). تحقيقات نشان داده، منبع دريافت فنلها و فلاونوئيدها 


$$
\text { سه تكرار ارزيابى گرديد. }
$$

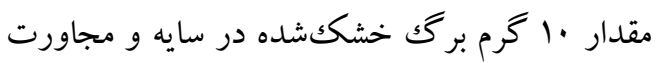

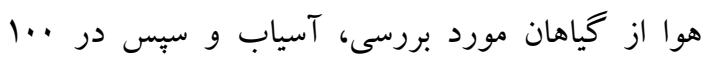

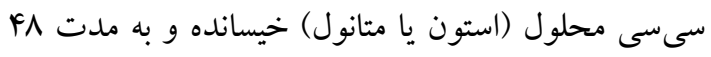

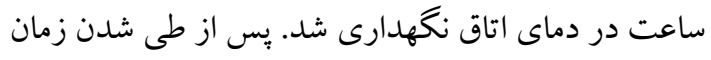

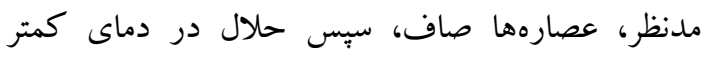

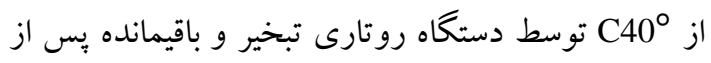

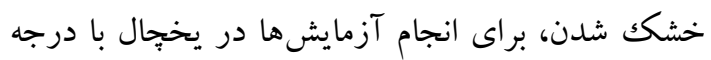

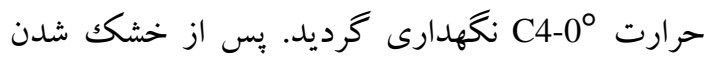
عصاره، ‥ ميلى گرم يودر عصاره را در اسى سكى متانل

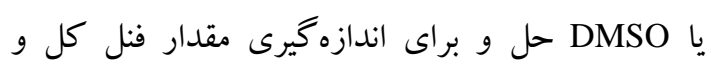

$$
\text { فلاونوئيد نخهدارى شد (19). }
$$

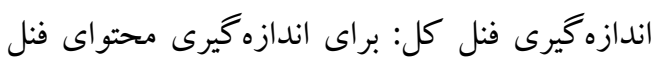
كل، به ... ميكروليتر از عصارة گياه، ب ميلىليتر كربنات

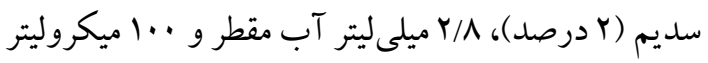

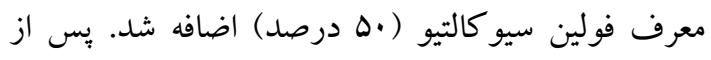
كذشت نيم ساعت، جذب آنها در طولموج •Vr نانومتر نسبت به شاهد ثبت گرديد. اسيد گاليكك بهعنوان استاندارد

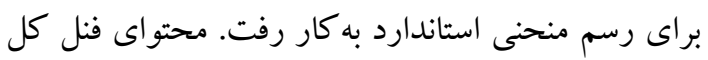

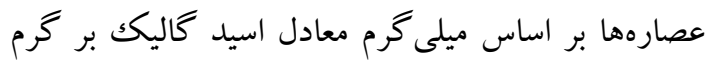
وزن خشك گياه گزارش شد ( r.).

اندازهيرى فلاونوئيد كل: براى سنجش ميز ميزان فلاونوئيد كل، به ه ميكروليتر از هر عصاره، ا ميلىليتر متانول ( •1 درصد)، 909 ميكروليتر محلول آلومينيوم كلرايد

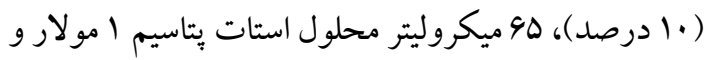

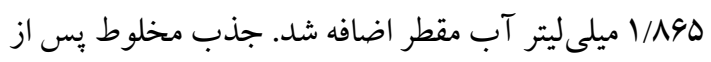
كذشت •F دقيقه، در طولموج هاب أنانومتر نسبت به بلانك اندازه گيرى گرديد. بلانكك حاوى تمام تر كيبات يادشده دونه

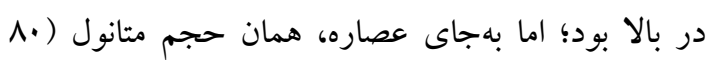

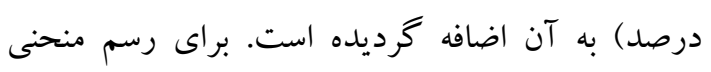

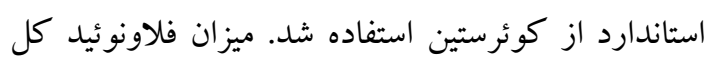
عصارهها بر اساس ميلى گرم معادل كوئرستين بر گرم وزن

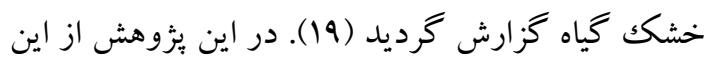
روش بهره گرفته شد.
تر كيبات فنلى بالا توصيه مى گردد (r) (I).

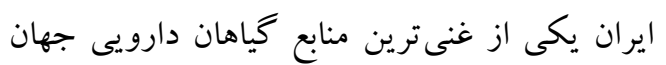

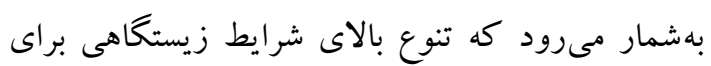

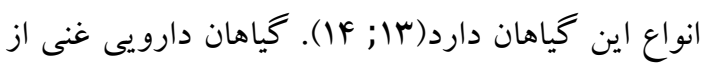
متابوليتهاى ثانويه و داراى مادهُ مؤثر اساسى بسيارى از از داروها هستند كه اين متابوليتها و مواد مؤثر اخرجها

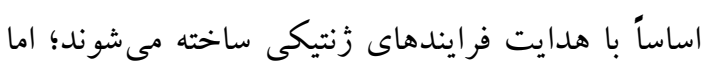
ساخت آنها بهطور بارزى تحت تأثير عوامل محيطى قرار

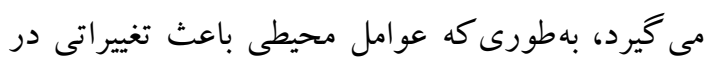

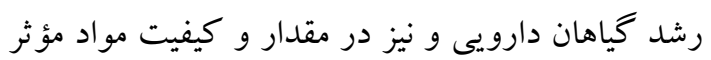

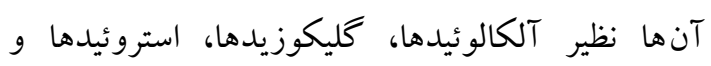

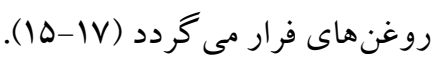

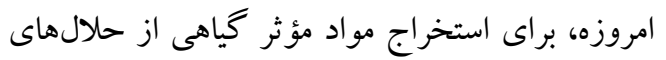
متفاوتى استفاده مىشود كه هر كدام مزايا و معايب خاص

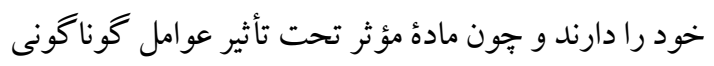
ازجمله نوع گياه، شرايط رويش، نوع حلال، روش مارد

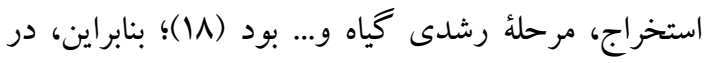
تحقيق حاضر سعى شد تا گياهان مختلف از منطقة رودان

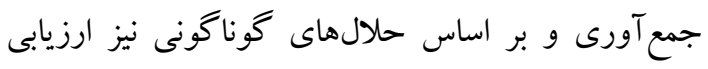

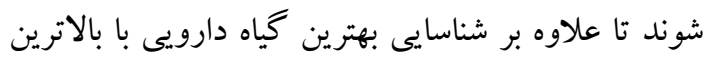
ميزان مواد فنلى و خواص آنتى اكسيدانى، بتوان تأثير هر كدام

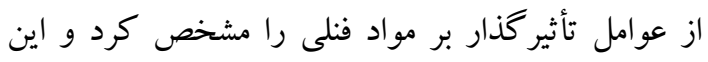

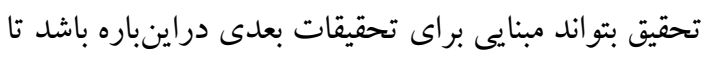

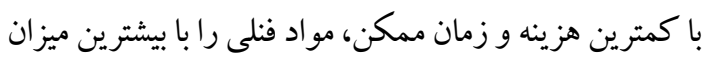
در گياهان مختلف استخراج و مقايسه نمود.

\section{مواد و روش ها}

تهيئ مواد گياهى و عصارة متانولى و استونى: در اين

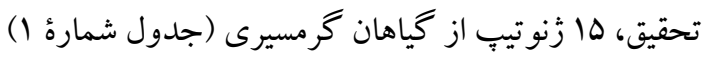

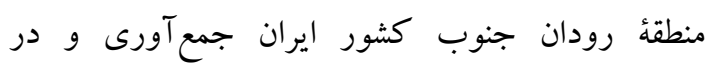

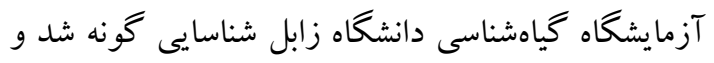
بر اساس دو نوع عصارهٔ متانلى و استونى، از لحاظ ميزان

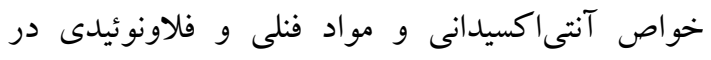

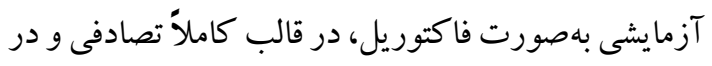


جدول شمارؤ ا. مشخصات گياهشاسى، محل جمع آورى و شكل برگك گياهان استفادهده

\begin{tabular}{|c|c|c|c|c|}
\hline شكل بر Fى & محل جمع آورى & اسم علمى & خانواده & ز زنوتيب \\
\hline & دهبارز & Ficus religiosa $\mathrm{L}$ & Moraceae & انجير معابد \\
\hline & كميز & Terminalia catappa & Combretaceae & لوز (كارم زنگى) \\
\hline & كميز & Ficus carica & Moraceae & 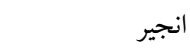 \\
\hline & بيكاه & Cordia myxa & Boraginaceae & سبستان، \\
\hline & دهبارز & Black mulberry & Moraceae & شاهتوت \\
\hline & دهبارز & Grewia asiatica & Malvaceae & 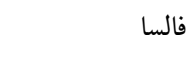 \\
\hline & كميز & Psidium guajava & Myrtaceae & 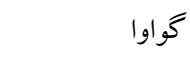 \\
\hline & بيكاه & Mangifera & Anacardiaceae & انبه | - إ \\
\hline & دهبارز & Mangifera & Anacardiaceae & انبه r - ان \\
\hline & خير آباد & Eucalypteae & Myrtaceae & اكالييتوس \\
\hline & خراجى & Syzygium cumini & Myrtaceae & جمبو \\
\hline & كميز & Ziziphus & Rhamnaceae & كنار 1 \\
\hline & بيكاه & $\begin{array}{l}\text { Citrullus } \\
\text { colocynthis }\end{array}$ & Cucurbitaceae & هندوانهُ ابوجهل \\
\hline & اسلام آباد & Ziziphus & Rhamnaceae & كنار r \\
\hline & برنطين & Punica granatum & Lythraceae & انار \\
\hline
\end{tabular}



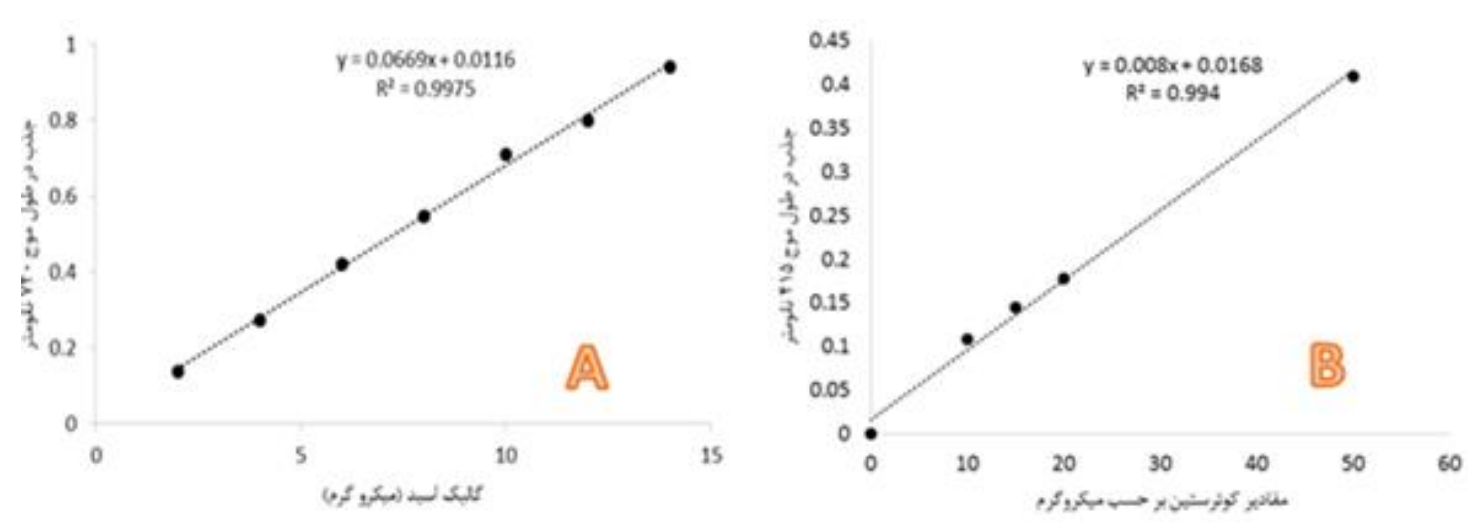

شكل شماره ا. منحنى استاندارد؛ كاليك اسيد براى اندازهيرى مقادير فنل (A)؛ كوئرستين براى اندازهيرى مقادير فلاونوئيد (B)

استفاده از حداقل تفاوت معنادار (LSD) در سطح ا درصد انجام كرديد.

إفته

عصارة استونى: نتايج تجزئُ واريانس نشان داد كه خواص آنتى اكسيدانى، فنل، فلاونوئيد تام و اثر متقابل كياه و DPPH براى عصارة استونى در سطح احتمال ا درصد معنى حادار بودند (جدول شماره Y). مقايسهُ ميانگين دادهها نشان داد كه عصارة استونى گياه اكاليتوس بيشترين ميزان

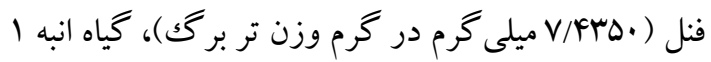
بيشترين ميزان فلاونوئيد (F/F/F ميلى گرم در گرم وزن

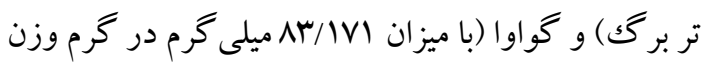
تر بركى) بيشترين ميزان خواص آنتى اكسيدانى را داشتند

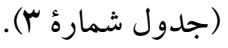

عصاره متانولى: نتايج تجزئُ واريانس نشان داد كه خو اص آنتى اكسيدانى، فنل، فلاونوئيد تام و اثر متقابل كياه و بPPH براى عصاره متانولى در سطح احتمال ا درصد
ارزيابى ميزان توانايى بهداماندازى راديكال يا سنجش خواص آنتىاكسيدانى: راديكال پيايدار دىفنيل يِيكريل هيدرازيل براى تعيين فعاليت بهداماندازى راديكال آزاد

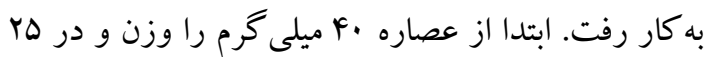
سىسى متانول حل مى كنيم و سبس از اين محلول سه

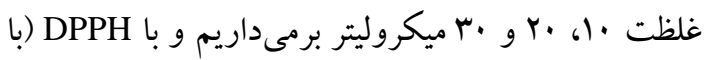
غلظت / • ميلى مول) به حجم F سىسى مىرسانيم و يّ از آن، در دماى اتاق به مدت ا ساعت مى گذاريم و درنهايت، جذب نورى را با طولموج اله نانومتر انجام مىدهيم. براى كنترل مثبت (شاهد) مىتوان از اسكوربيك اسيد استفاده كرد (Y) (Y).

$$
F=\frac{A_{b}-A_{s}}{A_{b}} * 100
$$

F مقدار بهداماندازى راديكال DPPH؛ Ab. جذب بلانك؛ As تجزيهوتحليل دادهها: بهمنظور محاسبات آمارى از

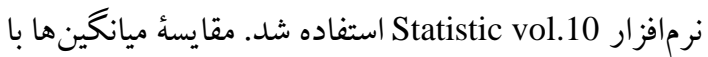

جدول شماره ז. تجزئُ واريانس خواص آنتىاكسيدانى عصارهُ استونى گياهان دارويى

\begin{tabular}{|c|c|c|c|}
\hline \multicolumn{2}{|c|}{ ميانكين مربعات } & \multirow{2}{*}{ درجة آزادى } & \multirow{2}{*}{ منابع تغيير ات } \\
\hline Mean of Square & Sum of Square & & \\
\hline$r r q \cdot \mid \varphi \cdot{ }^{* * * *}$ & 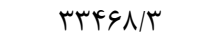 & If & Plant \\
\hline$r V V \cdot / T^{\prime * * * *}$ & $\Delta \Delta F \cdot / V$ & r & Consentra \\
\hline rqV/V & $111 r v / c$ & rᄉ & Plant*Consentra \\
\hline \multirow[t]{2}{*}{ I/FF } & $159 / 9$ & $q$. & Error \\
\hline & D. TVG/. & IrF & Total \\
\hline
\end{tabular}

، ، ns 
جدول شمارهُ Г. ارزيابى ميزان فنل، فلاونوئيد و خواص آنتىاكسيدانى عصارة استونى گياهان دارويى

\begin{tabular}{|c|c|c|c|}
\hline \multicolumn{3}{|c|}{ عصاره استونى } & \multirow{2}{*}{ كياه } \\
\hline خواص آنتى اكسيدانى & فلاونوئيد & فنل & \\
\hline 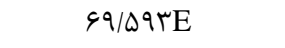 & $1 \cdot / 4 I V H$ & \&/·^१७C & انجير معابد \\
\hline GY/\AVF & $1 \wedge / \vee \Delta \cdot B$ & $\Gamma / \omega \cdot r V G$ & لوز (كارم زنخى) \\
\hline$r G / V \cdot V J$ & |r/•rGFG & $F / \| r \mid \Delta E$ & انجير \\
\hline$F Y / \Delta T \cdot H$ & $\mathrm{~F} / \Lambda \Lambda \mid \cdot J K$ & $I / \Delta / \Delta V J$ & سيستان \\
\hline$\Delta \Delta / V V T G$ & $9 / 19 \cdot \Delta \mathrm{J}$ & $\cdot / \Delta \Delta q \cdot \mathrm{K}$ & شاهتوت \\
\hline$V \varepsilon / \mu \cdot \mid B$ & F/DArrK & $r / \Delta \& r \Delta F G$ & 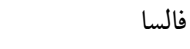 \\
\hline$\wedge r / \backslash \vee \backslash A$ & $\mid \& / \Delta \wedge r \mathrm{CDE}$ & T/qTVTEF & كواوا \\
\hline$\vee \& / \cdot \Delta V B C$ & Tr/TIFA & T/MTFFGH & انبه | \\
\hline$V \Delta / / \& H C$ & $|Q / F| V C D$ & T/YVA.I & 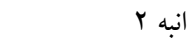 \\
\hline$V \cdot /$ $4 \hookrightarrow \mathrm{E}$ & $\mid Q / \Delta r \Leftrightarrow C$ & $V / F r \Delta \cdot A$ & اكاليتوس \\
\hline$V \cdot / r \cdot r E$ & $V / 919 \cdot I$ & GIDTrTB & جمبو \\
\hline VT/QTVD & $|F /| \& V D E F$ & 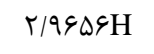 & كنار 1 \\
\hline $\mathrm{TV} / \Delta \varphi / I$ & $9 / 19 \cdot \Delta \mathrm{J}$ & $|/ / q| \Delta J$ & هندو انهُ ابو جهل \\
\hline$V \cdot / T r E$ & 11/9६4G & $F / G \Delta F V D$ & 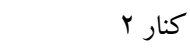 \\
\hline$V Y / \Delta G \mid D$ & Ir/9५१EF & $r / r q r \cdot I$ & 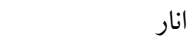 \\
\hline
\end{tabular}

ميانگين اثر متقابل گياه و سطوح DPPH نشان داد كه براى

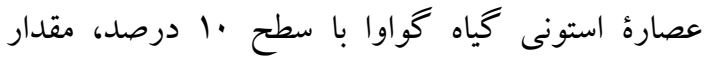

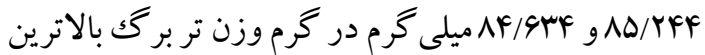

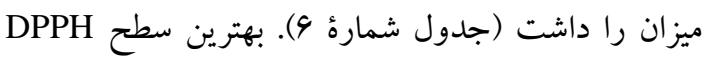
براى عصارة متانولى با ميزان 99/990 ميكرو گرم در ليتر،

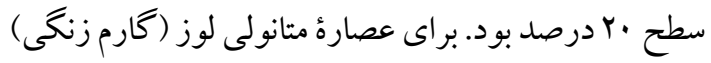

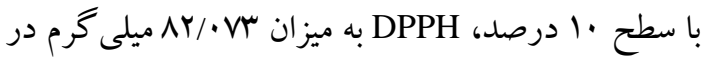

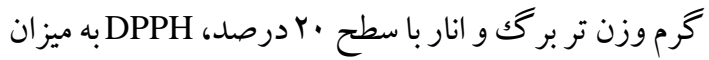

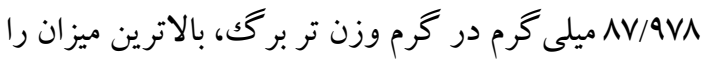
داشتند (جدول شمارة 9).
معنى רادار بودند (جدول شمارةٌ F). عصارة متانولى گياه

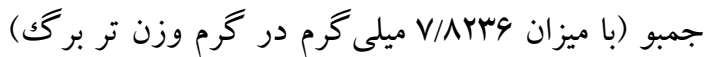
بيشترين ميزان فنل، عصارهٔ متانولى گياهان انبه ا و لوز

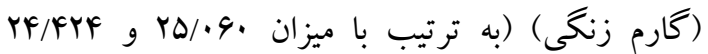

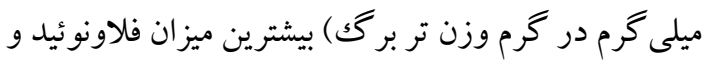

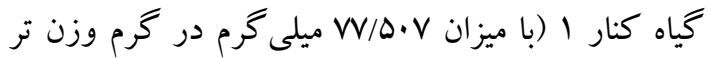

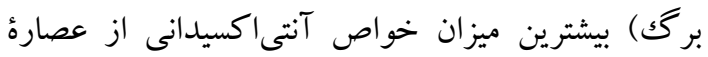
مثانولى را داشتند (جدول شماره ه). بهترين سطح DPPH براى عصاره استونى با ميزان

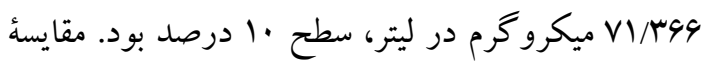

جدول شمارهُ ع. تجزئ واريانس خواص آنتىاكسيدانى عصارهُ متانولى گياهان دارويى

\begin{tabular}{|c|c|c|c|}
\hline \multicolumn{2}{|c|}{ ميانكين مربعات } & \multirow{2}{*}{ درجة آزادى } & \multirow{2}{*}{ منابع تغييرات } \\
\hline Mean of Square & Sum of Square & & \\
\hline$|\Pi| V / \Delta \varphi^{* * *}$ & 1 1NFE/q & 14 & Plant \\
\hline$F V / T \Lambda^{* * *}$ & $94 / 1$ & $r$ & Consentra \\
\hline 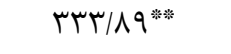 & $q r<q / \cdot$ & $r \Lambda$ & Plant*Consentra \\
\hline \multirow[t]{2}{*}{ 1/Dr } & $\mid r V / F$ & 9 . & Error \\
\hline & $r N \cdot r d / l$ & IMF & Total \\
\hline
\end{tabular}


جدول شماره ه. ارزيابى ميزان فنل، فلاونوئيد و خواص آنتىاكسيدانى عصارة متانولى گياهان دارويى

\begin{tabular}{|c|c|c|c|}
\hline \multicolumn{3}{|c|}{ عصاره متانولى } & \multirow{2}{*}{ كياه } \\
\hline خواص آنتى اكسيدانى & فلاونوئيد & 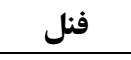 & \\
\hline$q 4 / \Delta \Delta r H$ & $\Delta / V I F r F G$ & F/VFFFD & انجير معابد \\
\hline Vr/raAC & YF/FGFA & $\Delta / 94 I T C$ & لوز (گارم زنگیى) \\
\hline $\mathrm{rq} / \Delta 99 \mathrm{~J}$ & F/OYKAD & $\cdot / r \cdot r I$ & انجير \\
\hline $\mathrm{H} \& \mathrm{r} / 9 \Delta \mathrm{V}$ & $\Lambda / \Delta 1 / 9 E$ & $1 / \Delta F \Delta G \mathrm{H}$ & سِّتان \\
\hline GV/VDIG & ه/^९५৭F & •/MFAI & شاهتوت \\
\hline VI/arrCD & $19 / \cdot V \mid B$ & ./DraII & فالسا \\
\hline$V \cdot / \mu F \Delta E$ & $1 r / \Delta 9 \cdot C D$ & $r / q \cdot v r E$ & كواوا \\
\hline$\Delta F / \cdots V I$ & $\mathrm{rQ} / \cdot 9 \cdot \mathrm{A}$ & $\Delta / \cdot Y \wedge F D$ & | - انبه | \\
\hline VD/AFrB & $10 / \cdots B$ & $r / r \cdot r r G$ & انبه r إن \\
\hline $9 \wedge / 9 \Delta 1 \mathrm{~F}$ & $11 /$ rqAD & V/rFarB & اكالييتوس \\
\hline GF/VIIH & V/VץNIE & V/ArrGA & جمبو \\
\hline$V / \Delta \cdot V A$ & Ir/DIYC & $1 / 9 \cdot \Delta F H$ & كنار 1 \\
\hline KN/FFFJ & $\Delta / Y r \wedge I F G$ & $1 /$ ra91H & هندوانهُ ابو جهل \\
\hline V//19DE & $\Lambda / \cdot 9 \Delta r E$ & $r / \mu . . F$ & 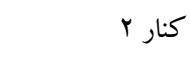 \\
\hline$V \Delta / \Delta r r B$ & $V / Y 919 \mathrm{E}$ & $1 / \Delta q \cdot F H$ & انار \\
\hline
\end{tabular}

جدول شماره جا. ارزيابى اثر متقابل خواص آنتىاكسيدانى گياه* عصارة گياهان دارويى

\begin{tabular}{|c|c|c|c|c|c|c|}
\hline \multicolumn{3}{|c|}{ عصاره متانولى } & \multicolumn{3}{|c|}{ عصارة استونى } & \multirow{3}{*}{ Plant } \\
\hline \multicolumn{3}{|c|}{ عصاره } & \multicolumn{3}{|c|}{ عصاره } & \\
\hline$r$. & $r$. & 1. & $r$. & $r$. & 1. & \\
\hline $9 \cdot / 4 M A T$ & $9 \Delta / 91 \cdot P Q R S$ & GV/DGIMNOP & ят/rqזNO & GQ/ITTMN & $\Lambda \cdot / r \hookrightarrow 9 \mathrm{C}$ & انجير معابد \\
\hline ध১/r^१QRS & צq/ศTIJKLM & $\Lambda T / \cdot V r A$ & FY/qTVT & GV/TIVKL & AY/rIVB & لوز (كارم زنكى) \\
\hline FI/AIrX & GV/TFVNOPQ & $q / \xi 4 \cdot a$ & $|F / D| Y Y$ & rq/rq.U & $\Delta D /$ FFY & انجير \\
\hline$\Delta F / q r G U$ & я4/яqrRS & VT/YFTGH & $r T / 190 X$ & $\varphi \cdot /$ « P & $F \Delta / \cdots S$ & سקֶتان \\
\hline 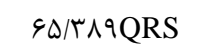 & צヘ/rqrKLMNO & $\varsigma 9 / \Delta V \cdot I J K L$ & $\Delta \& / A Y Q Q$ & GT/MIVO & FN/IVIR & شاتوت \\
\hline$\vee \varepsilon / / 9 \cdot \mathrm{CDE}$ & $\varepsilon N|q \uparrow| \mathrm{KLMN}$ & $\vee \cdot / 9 \& \uparrow G H I J$ & $V r / \cdot 4 q F G$ & VV/GTVD & VV/aTVD & فالسا \\
\hline VT/FVFFG & GN/rqrKLMNO & $\vee \cdot /$ 9 VHIJK & $V q / G K Y C D$ & NF/grFA & ND/TFFA & كواوا \\
\hline$\varphi \& \mid \Lambda \cdot \varphi \mathrm{W}$ & $\Delta 1 / T r \cdot V$ & ८५/৭१८S & $\vee F / \wedge V \wedge E F$ & दq/GTYIJ & $\wedge r / 9 \Delta 9 \mathrm{AB}$ & انبه | \\
\hline VF/rTrEF & $v / / \cdots r B C D$ & $\vee \varepsilon / 19 \cdot \mathrm{CDE}$ & $V F / r q \cdot E F$ & $V V / \Lambda \cdot \Delta D$ & VT/YquFG & انبه r \\
\hline GN/rarKLMNO & ৭N/৭৭·JKLMN & $৭ 9 / \Delta V \cdot I J K L$ & яq//ץяIJK & ЯN/Tq४JKL & $\vee r / 9 \Delta १ E F G$ & اكاليتوس \\
\hline$\varepsilon \Delta / \vee r \wedge P Q R S$ & $4 \cdot 10111 \mathrm{~T}$ & \&V/qFFLMNO & $\varepsilon \varphi / \Delta \wedge \Delta \mathrm{LM}$ & $\mathrm{V} \cdot / \cdots \mathrm{IJ}$ & $V F / \cdot r F E F G$ & جمبو \\
\hline VG/FrrCD & VV/qurBC & $\vee \wedge / / \& \Delta B C$ & \&N/ץqนJKL & Gq/दTFIJ & $\Lambda r / \varepsilon \wedge r B$ & كنار 1 \\
\hline$\varepsilon \cdot / \cdot \nvdash \varepsilon T$ & $r \Delta / \varepsilon \Delta \varphi \mathrm{Y}$ & $19 / 9 Y \wedge Z$ & TF/IFEW & rq/Vఎ\&V & $\triangle \Lambda / \vee \Lambda \cdot P$ & هندوانةُ ابوجهل \\
\hline s/DQIOPQR & VI/DFDGHI & $V \Delta / Y \& \mid D E$ & $\varepsilon F / T \wedge \& N$ & $V \cdot / \wedge \Delta \uparrow H I$ & VD/TFFE & كنار r \\
\hline$\checkmark \cdot / r \& V H I J K$ & 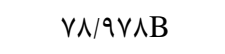 & $V V / r \Delta T B C$ & VT/\&rqGH & $V \cdot / r \hookrightarrow 9 I$ & $\vee F / \wedge \vee \wedge E F$ & انار \\
\hline
\end{tabular}

سبس جمبو (mg/gFW52/6) ، فلاونوئيد در انبه ا (mg/gFW21/23) و و سيس لوز (كارم زنكى)

(mg/gFW75/18)
بحث و نتيجه تيرى

اين يزوهش نتايج نشان داد كه حلال استونى باعث بيشترين استخراج فنل در اكالييتوس (mg/gFW43/7) و 
و فلاونوئيد كل بهترين عملكرد را در ميان ساير حلالها

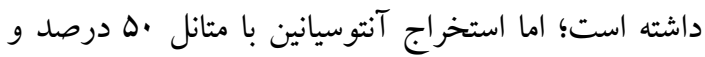

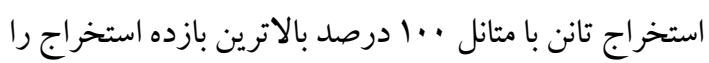
داشتند. در همة موارد، آب كمترين قابليت استخراج

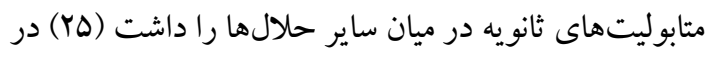
تحقيق حاضر نيز، عصارة متانولى از بيشترين بازده در استخراج مو اد فنلى و فلاونوئيدى برخوردار بوداد.

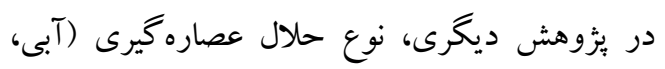

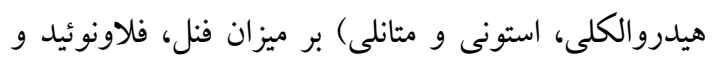

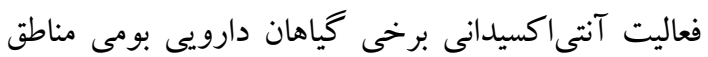
مختلف ايران بررسى شد و به اين نتيجه رسيدند كه متانول مهمترين حلال براى استخراج مواد فنلى و بررسى خاصيت اكسيدانى بوده است (YY). در تحقيق حاضر نيز، با آنكه عصارة متانولى بيشترين بازده را در استخراج مواد فنلى و فلاونوئيدى داشت؛ اما بيشترين خاصيت آنتىاكسيدانى از عصارة استونى بهدست آمد؛ پِ بسته به هدف از آزمايش، بايد نوع عصارة كاربردى را انتخاب كرد. در يُزوهى، ميزان فنل و فلاونوئيد تام و فعاليت آنتىاكسيدانى يوست درختان راش، ممرز و صنوبر بررسى

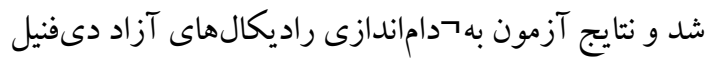
بيكريل هيدرازيل نشان داده است كه غلظت مهار •هـ درصد

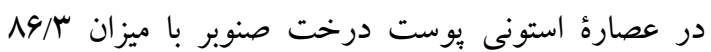
ميكرو گرم بر ميلىليتر بيشتر از درخت راش و ممرز بودهن است (Y))، هرجند در تحقيق ديخرى، متانول مهمترين حلال براى استخراج مواد فنلى و بررسى خاصيت اكسيدانى درئي كزارش شده است (YF). در تحقيق حاضر، بيشترين خاصيت

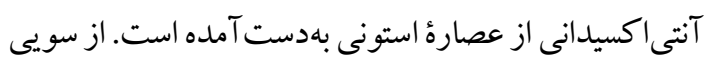

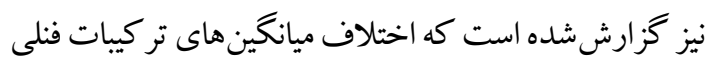
و فلاونوئيدى تام عصارهها تحت تأثير سه عامل جمعيت،

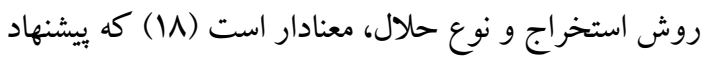

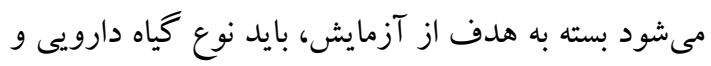
همجِين نوع عصارة كاربردى را بررسى و انتخاب كرد. كزارششده است كه عصاره نعناع علاوه بر اينكه بيشترين تر كيات فنلى و فلاونوئيدى رادارد، بيشترين فعاليت

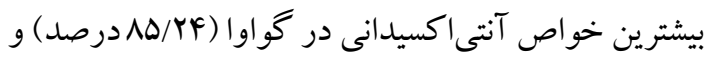

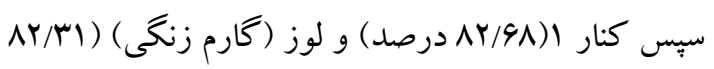
درصد) شده است. حلال متانلى سبب استخراج بيشترين

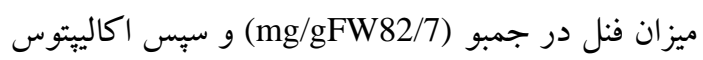

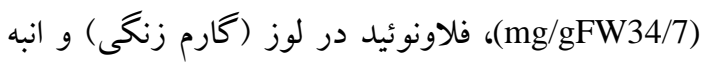

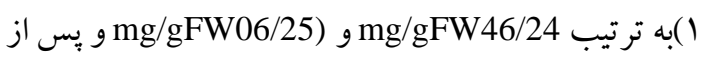
آن، فالسا (mg/gFW07/16) و كنار التيب (mg/gFW51/13) و بيشترين خواص آنتىاكسيدانى در لوز (كارم زنكى)

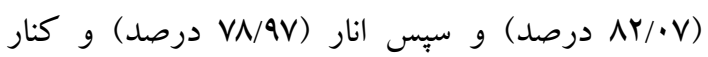

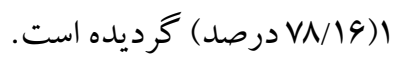

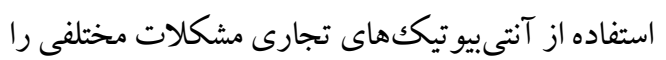

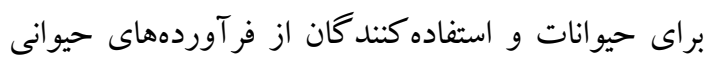

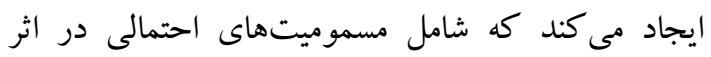
مصرف دارو، باقى ماندن دارو در بافتها و ويدايش سويههاى مقاوم به عوامل ضدبا كتريايى است (YY). كياهان از هزاران سال بيش نقش بسيار مهمى در حفظ سلامتى و

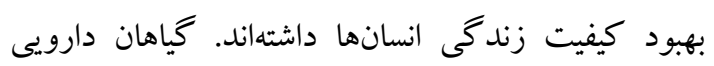
خواص مفيدى دارند كه ازجمله مىتوان به خاصيت ضدباكتريايى، ضدانكلى، ضدقارجى و آنتىاكسيدانى اشاره

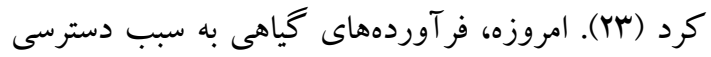

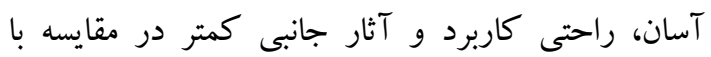
فر آوردههاى شيميايى، براى درمان بيشتر بيمارىهاى انسان و ورد

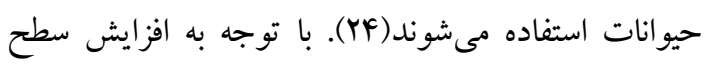

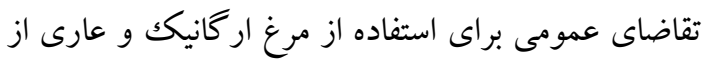

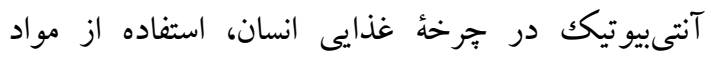

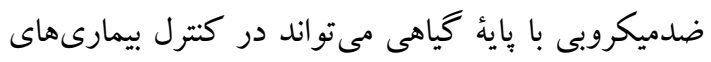

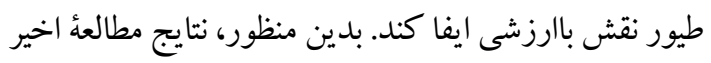

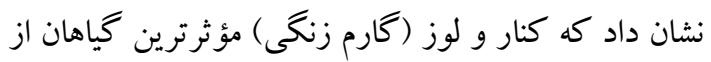
لحاظ حضور مواد و خاصيت آنتى اكسيدانى بودهاند. در تحقيقى، تأثير تيمار حلالهاى متانول، اتانول، استون

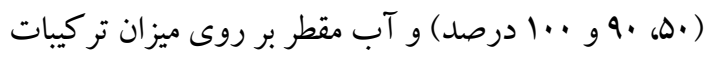
آنتىاكسيدانى (فنل كل، تاننها، فلاونوئيدها، آنتوسيانينها)

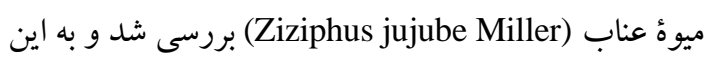
نتيجه رسيدند كه استون •هدرصد در استخراج تر كيبات فنل 


$$
\begin{aligned}
& \text { مهندسى زنتيكك و نشانگرهاى مولكولى قادر است كارايى } \\
& \text { كياهان را بهعنوان منابع تجديديذير، براى توليد دارو افزايش } \\
& \text { دهد (اس-سM)؛ درنتيجه، استفاده صحيح از گياهان دارويى، } \\
& \text { شناخت و بررسى متابوليتهاى ثانويه و تر كيبات آنها بسيار }
\end{aligned}
$$

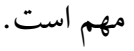

$$
\begin{aligned}
& \text { نتايج اين تحقيق نشان داد كه متانول مهمترين حلال } \\
& \text { براى استخراج مواد فنلى و استون براى بررسى خاصيت } \\
& \text { اكسيدانى است و كنار و لوز (كارم زنكى) مؤثرترين كياهان } \\
& \text { از لحاظ حضور مواد و خاصيت آنتى كسيدانى هستند. }
\end{aligned}
$$

\section{تشكر و قدردانى}

هزينهُ انجام اين يثزوهش توسط معاونت يثروهشى دانشگاه آزاد اسلامى واحد رودان با شماره مجوز

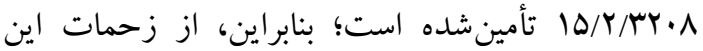
دانشگاه تشكر و قدردانى مى گردد.

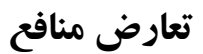

نويسند گان اعلام مى كنند كه تضاد منافعى در اين

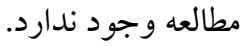

كد اخلاق: IR.UOZ.REC.1399.008

\section{References}

1. Fazelinasab B, Fooladvand Z. A review on Iranian Carum copticum L. composition and biological activities. European Med Plant 2016; 12: 1-8. doi.10.9734/EJMP/2016/17584

2. Mehrabi AA, Fazelinasab B. Invitro culture of Allium scorodoprasum spp. Rotundum callus induction somatic embryogenesis and direct bulblet formation. Intl J Agri Crop Sci 2012; 4: 1-7.

3. Burt S. Essential oils: their antibacterial properties and potential applications in foods a review. Int J Food Microbiol 2004; 94: 223-53. doi. 10.1016/j.ijfoodmicro.2004.03.022

4. Fooladvand Z, Fazelinasab B. Antibacterial activities of stachys Lavandulifolia vahl. extract against eight bacteria. J Herb Drug Int Med 2014; 5: 13-8.

5. Beigomi M, Biabangard A, Rohani R. Evaluation of antimicrobial effects of Rosemary and Withania somnifera methanol extract prepared by ultrasound waveform on Escherichia coli biofilm isolated from urinary tract infection. Mic Environe 2021; 1: 17-25. doi. 10.54458/mev.v1i01.6670

6. Wach A, Pyrzynska K, Biesaga M. Quercetin content in some food and herbal samples. Food Chem 2007;
آنتى اكسيدانى نيز داشته است (YV) و همجِنين رابطؤ مستقيم

ميان فعاليت بالاى آنتىاكسيدانى عصارهُ رزمارى با محتو اى فنلى (YN) و تركيبات يلى فنلى عصارهُ متانولى جند كياه بومى مازندران با فعاليت آنتى اكسيدانى تائيد شده

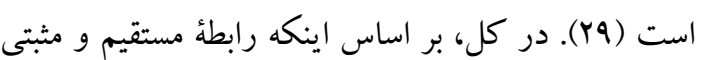
ميان ميزان تركيبات فنلى و فلاونوئيدى و فعاليت آنتى اكسيدان وجود دارد(YF). در تحقيق حاضر نيز مشاهده شد گياهانى مانند كنار و لوز (كارم زنخىى) كه داراى بيشترين ميزان تركيبات فنلى بودهاند، بيشترين خاصيت آنتى اكسيدانى رانيز داشتهاند. بعضى از گياهان دارويى زيستخاههاى طبيعى محدودى ليرى دارند و بسته به شرايط محيطى و جغرافيايى محل رويش كياه، جمع آورى آنها با مشكلاتى مواجه است (·r). غلظت يايين اين تر كيبات در كياه، محدوديت منابع طبيعى، تخريب روزافزون جنگل ها، مراتع و فضاى سبز، نابودى كونههاى متنوع گياهى و جانورى، مشكلات مرتبط با اهلى كردن و كشت زراعى اين گياهان، توجه محققين را به استفاده از راهكارهاى بيوتكنولوزى براى افزايش توليد و بهرهورى كياهان دارويى معطوف كرده است. بيوتكنولوزى با بهرهگیرى از علوم مختلف مانند بيولوزى، بيوشيمى، زنتيك و... و با استفاده از راهكارهاى كشت سلولها، اندامها،

100: 699-704. doi.10.1016/j.foodchem.2005.10.028

7. Sharma R, Samant S, Sharma P, Devi S. Evaluation of antioxidant activities of Withania somnifera leaves growing in natural habitats of Northwest Himalaya India. J Med Plant Res 2012; 6: 657-61. doi.10.5897/JMPR11.257

8. Shrivastava A, Roy S. Cucurbitaceae a ethnomedicinally important vegetable family. J Med PlantStud 2013; 1: 16-20.

9. Bagchi D, Bagchi M, Stohs SJ, Das DK, Ray SD, Kuszynski CA, et al. Free radicals and grape seed proanthocyanidin extract importance in human health and disease prevention. Toxicology 2000; 148: 187-97. doi.10.1016/S0300-483X(00)00210-9

10. Mirzaei A, Mohammadi J, Mirzaei N, Mirzaei M. The antioxidant capacities and total phenolic contents of some medicinal plants in Iran. J Fasa Uni Med Sci 2011; 1: 160-67.

11. Mathew S, Abraham TE. In vitro antioxidant activity and scavenging effects of Cinnamomum verum leaf extract assayed by different methodologies. Food Chem Toxicol 2006; 44: 198206. doi.10.1016/j.fct.2005.06.013 
12. Sottero B, Leonarduzzi G, Testa G, Gargiulo S, Poli G, Biasi F. Lipid Oxidation Derived Aldehydes and Oxysterols between Health and Disease. European J Lip Sci Technol 2018; 2:1700047. doi.10.1002/ejlt.201700047

13. Jahantigh $M$, ahmadi $H$. Analysis of the antimicrobial activity of Ashurak extracts prepared with different solvents on Klebsiella pneumoniae and Shigella dysentery isolated from poultry faeces. Mic Environ2021; 1: 54-62. doi. 10.54458/mev.v1i01.6673

14. Shahraki-Mojahed L, Behzadmehr R, Beigomi Z. Antimicrobial effects of ethanol methanol and ethyl acetate Teucrium polium and Citrullus colocynthis extract on Pseudomonas aeruginosa. Mic Environ2021; 1: 26-32. doi.10.54458/ mev.v1i01.6671

15. Karabulut F, Parray JA, Mir MY. Emerging trends for Harnessing plant metabolome and microbiome for sustainable food production. Mic Environ2021; 1: 33-53 doi. 10.54458/mev.v1i01.6672

16. Parray JA, Ali U, Mir MY, Shameem N. A high throughputs and consistent method for the sampling and isolation of endophytic bacteria allied to high altitude the medicinal plant Arnebia benthamii. Mic Environ 2021; 1: 1-6. doi.10.54458/mev.v1i01.6668

17. Shafi S, Bandh SA, Shameem N. Interpreting proteobacteria diversity through $16 \mathrm{~S}$ rRNA analysis in Manasbal lake Kashmir. Mic Environ 2021; 1: 716. doi. 10.54458/mev.v1i01.6669

18. Saboura A, Ahmadi A, Zeinali A, Parsa M. [Comparison between the contents of phenolic and flavonoid compounds and aerial part antioxidant activity in scutellaria pinnatifida in two NorthIranian populations]. J Rafsanjan Uni Med Sci 2014; 13: 249-66. (Persian)

19. Chang CC, Yang MH, Wen HM, Chern JC. Estimation of total flavonoid content in propolis by two complementary colorimetric methods. J Food Drug Analy 2002; 10: 178-82.

20. Meda A, Lamien CE, Romito M, Millogo J, Nacoulma OG. Determination of the total phenolic flavonoid and proline contents in Burkina Fasan honey as well as their radical scavenging activity. Food Chem 2005; 91: 571-77. doi.10.1016/ j.foodchem.2004.10.006

21. Ebrahimzadeh MA, Hosseinimehr SJ, Hamidinia A, Jafari M. Antioxidant and free radical scavenging activity of Feijoa sallowiana fruits peel and leaves. Pharmacol Online 2008; 1: 7-14.
22. Javed M, Durrani F, Hafeez A, Khan R, Ahmad I. Extract of plant mixture on carcass quality of broiler chicks. Arpn J Agri Biol Sci 2006; 1: 115-21.

23. Stickel F, Schuppan D. Herbal medicine in the treatment of liver diseases. Dig Liv Dis 2007; 39: 293-304.

24. Fazelinasab B, Moshtaghi N, Forouzandeh M. Effect of solvent extraction on phenol flavonoids and antioxidant activity of some Iranian native herbs. Sci J Ilam Uni Med Sci2019; 27: 14-26 doi. 10.29252/sjimu.27.3.14

25. Davarynejad G, Taghizadeh S, Asili J. Effect of different solvents on total phenolic contents and antioxidant activity of Zizyphus jujube Miller Fruits. J Horticul Sci 2017; 31: 158-66. doi. 10.22067/jhorts4.v0i0.47986

26. Fazli R, Nazarnezhad N, Ebrahimzadeh MA. Evaluation of phenols and flavonoids and antioxidant activity of the bark of beech, hornbeam and pine. J Forest Wood Prod2013; 66: 339-42.

27. radiation-processed lamb meat. Food Chem 2007; 100: 451-58. doi. 10.1016/j.foodchem.2005.09.066

28. Elmastas M, Dermirtas I, Isildak O, Aboulenein HY. Antioxidant activity of $\mathrm{S}$ carvone isolated from spearmint Mentha spicata L. Fam Lamiaceae. J Liq Chromatograph Rel Technol 2006; 29: 1465-75. doi.10.1080/10826070600674893

29. Fathiazad F, Ahmadiashtiani H, Rezazadeh S, Jamshidi M, Mazandarani M, Khaki A. Study on phenolics and antioxidant activity of some selected plant of Mazandaran province. J Med Plant 2010; 9: 177-83.

30. medicinal properties of mastic. Int J Adv Biol Biomed Res2014; 2: 2155-61.

31. Hadizadeh H, Mohebodini M, Esmaeilpoor B, Chamani E. studies on callus induction and regeneration of medicinal plant chicory Cichorium intybus L. from Leaf and Petiole Explants. J Horticul Sci2015; 29: 621-30. doi.10.22067/ jhorts4.v29i4.32672

32. Fazelinasab B, Masour O, Mehdi A. Estimate of callus induction and volume immature and mature embryo culture and respons to in vitro salt resistance in presence of $\mathrm{NaCL}$ and $\mathrm{ABA}$ in salt tolerant wheat cultivars. Int Agri Crop Sci 2012; 4: 8-16.

33. Rasouli H, Fazeli-Nasab B. Structural validation and homology modeling of LEA 2 protein in bread wheat. Am Eurasian J Agri Environ Sci 2014; 14: 1044-48. doi. 10.5829/idosi.aejaes.2014.14.10.12424 